\title{
Monitoring and Evaluating the Performance of Teachers Through the Process of Observation in the Classroom
}

\author{
PhD. Lon Laska \\ University Colege "FAMA" in Prishtina \\ lon. laska@hotmail.com
}

+37745901803

\begin{abstract}
When we discuss about the framework of the teaching hour, we can conclude that it is the main axis of the work of teachers in the school institutions. However, during the recent years it has been a subject of discussion the idea that learning timeframe has changed in all its dimensions or aspects. Then, the question arises as to how much really the class teaching has changed so far? What's the professional level of preparedness of the teachers, in order to achieve a successful teaching hour? In this regard though, the evaluation of a teaching class, it should not only be done by the competent persons, but they must be also prepared in all the professional aspects. In this paper we will not talk about the learning and observation process in itself as a method of teaching and learning, but we will be focused mainly on the observation which is performed by the monitoring inspectors, the school director etc. during the teaching and educational process. The observation as a method it has mainly been used to supplement and verify the accuracy of the other methods. So far, the monitoring teamwork should pay attention to the process of observation, by including all the facts, the situations and aspects that are associated with the monitoring facilities, including all necessary aspects that help us find the truth and accuracy of the issues that we are being interested at.The methods, techniques and strategies enable us to objectively monitor and evaluate, in an effective and useful way, therefore the planning and methodology, as well as their use, are the main "pillars" of monitoring / evaluation of teaching performance. Thus, these methods and techniques enable us collecting relevant data and information, which are related to the performance of teachers on the basis of the measures and actions for corrections, improvements, promotions, incentives, licensing and full accountability. What methods, techniques and strategies we are going to use, it depends on the type of our monitoring and evaluation objectives. Also, it depends on whether we are dealing with the external or internal monitoring and evaluation process. In this paper we will try to present the observation method, such as an effective method for collecting data and evaluating the work of teachers. We will also examine some of the key aspects of observation: the observation planning, preparation, monitoring, the undergoing process of observation and the analysis after observation.
\end{abstract}

Keywords: observation, the process of data collection, performance, evaluation.

\section{Introduction}

The survey is one of the crucial elements of the collecting data during the MMV teacher performance. Moreover, at the first regard it is thought that observation it simple process as a method in itself, but it is actually quite complex, because during the monitoring process there seems to be occurring a couple of complex aspects within a short period of time. As Mathews states: "The survey is a data collection through human senses (Matthews, B. \& Ross, L., 2010). So, the observation is a very complex process, by taking into account the fact that we are dealing with a several human senses, and during the process the monitoring responsible team not only uses the sense of sight, hearing, etc. but as well as a coordination and combining of these common elements. 
The observation as a method of inspection is the sensory process that includes the contemplation of a fact, phenomenon, process, event, or a reality in the educational institutions for the purpose of inspection / assessment (KIPA, 2011).

There are several ways of providing information relating to the subject of monitoring / inspection, but the most effective ways of it are considered the participation in classes, laboratories, and sports' facilities, monitoring the learning process or activity that takes place (KIPA, 2011).

Another useful way of collecting data is even talking to the students about many aspects of school life, regarding their level of satisfaction with the work of teachers, for example. Also talking with the teachers about what went well or if there were presented any difficulty on understanding the ways of presenting, in order to find ways to improve, then all those aspects discussed have to deal with the teacher performance and the possible ways of improving them, in the case it is necessary.

The process of observation in the classes is a more effective way to gather data and provide direct inputs. Thus, directly from this observation, we will learn many aspects which will help us to give an accurate judgment.

The monitoring / inspection as a process, is based on several aspects, including the main aspects of the inspection that supports the judgments "on student outcomes, the effectiveness of the use of didactic / laboratory means of learning, the directing and managing of the classes and as well as using all the given opportunities to improve them (KIPA, 2011).

The observations in the classes help us to ascertain the actual situation of the majority of aspects, these help us monitor / inspect for objective assessment and recommendations for improvement in those areas where there are serious weaknesses or potential vulnerabilities. An observation followed by a critical reflection of the data that are provided to show the reality, life obstacles and classroom assessments (Sadker, M. \& Sadker, D., 1997). During the monitoring / inspection of the educational institution, the monitors withhold the continual contacts with teachers and staff, providing support and advice on observations in classes and the quality of work in general. The time that the monitors spend in the institution, should be used for professional conversation, the teaching level and cooperation in the future, in order to improve the quality of teacher performance. They can be held through informal talks with inspectors, while they remain in the institution, sharing positive experiences or related to their findings during the observation classes. All these aspects help to break the dividing wall between the teacher monitors and it contributes on creating a positive climate of understanding and cooperation.

The leader of the group of monitoring / inspection, every day meets with the school principal in order to inform about the findings of the monitoring process. From these meetings, the Director may introduce additional data, presenting the views of staff for monitoring / inspection or he/she will be informed of potential concerns.

Also, the monitors / inspectors meet the students, from conversations with students they can understand how they feel at school, and what are their needs and requirements. Even though, the suggestions they may have for improving various aspects, can be asked about the process of learning, involvement in various activities.

\section{Monitoring and evaluation of teacher performance in the classroom}

The Monitoring and evaluation of the teachers during an hour lesson, is one of the most important works of the inspector and the school principal as well. The director (monitor) of the school, by observing the classes and analyzes he often appreciates, knows what is happening in his school (ISP, 2003). If the observations are infrequent, or after the end of the observing process they are not followed with adequate analyzes, then they will have no value, because they have been formally made. The monitor should correctly recognizes the performance of each teacher. In order to achieve this, there must be developed a systematic monitoring and evaluation of the class and the work of teachers. Not only that, but as far as the observer observes classes, the more he recognizes high school students. The monitor (director, inspector, etc. ), must possibly recognize all students, in order to recognize their individual features of mental work, inclinations, desires and abilities. This can only be achieved through a systematic observation of teaching process as a whole.

Besides periodic observations, an important place in the work of the school principal in this case has the system analysis of teaching classes. So, the school principal monitors to the same teacher a couple of those teaching lessons, which will include some of the classes, or a thematic as a whole. The monitoring and evaluation of a system of lessons, creates the 
opportunity of the monitors to determine the effectiveness, impact of the advice of its recommendations. Before the start of the school year or during certain periods, the monitor (school director or inspector) plans which teachers will be monitored and assessed during the process.

\section{The observacion in the classroom}

The classroom observation is a basic strategy for the professional development of teachers. From this observation the monitor should give full conclusions as to the performance of each teacher and the conclusions must be drawn in order to connect with his individual improvement. The experience of many countries has shown that these observations should relate to the overall development program of teachers within the school. Some of the key aspects of the survey are:

Figure 1. The main aspects of the observation

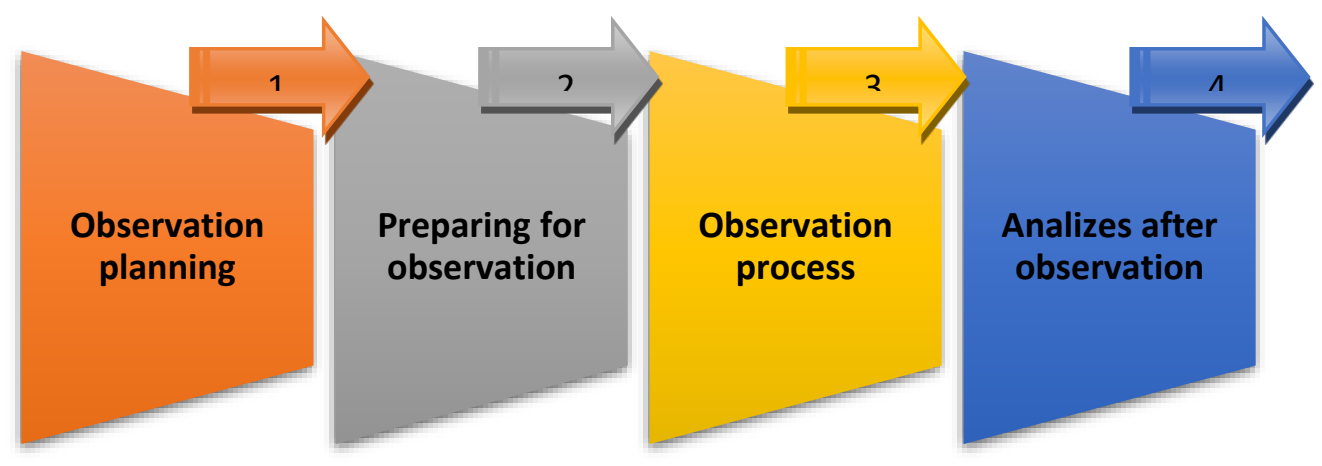

\section{1. The Observation Planning}

Që në fillim të vitit shkollor, monitoruesi planifikon vëzhgimin e mësimdhënësve, me qëllim që të konstatohet niveli i përgatitjes profesionale dhe pedagogjike dhe nga kjo nxjerrim përfundime për veprimet e mëtutjeshme. Mësimdhënësit e rinj, duhet të vëzhgohen që në ditët e para të shkollës. Pastaj nga monitoruesi, duhet të planifikohen vëzhgimet periodike, në periudha kohe të tilla, që mësimdhënësit të kenë kohë të reflektojnë ndaj këshillave. Njëkohësisht, në këto vëzhgime shihet edhe masa e reflektimit të mësimdhënësve. Poashtu është shumë e dobishme që vetë mësimdhënësit të realizojnë një numër vëzhgimesh tek njeri-tjetri. Vëzhgimin duhet shikuar si një strategji për përmirësimin e mësimdhënies, me anën e vizitave reciproke.

Since the beginning of the school year, the monitor plans for teachers' surveillance, in order to ascertain their professional and pedagogical level and to draw conclusions from it for further action. The young teachers should be observed, since the first days of school year. Then the monitor must be planning for the periodic observations in such periods that the teachers have additional or sufficient time to reflect on advice. At the same time, these observations can be seen in the reflection of teachers' measures. It is also very useful to teachers themselves to realize a number of observations to each other. The observation should be seen as a strategy to improve teaching, through mutual visits and sharing of the positive experiences.

The observations may be announced or unannounced. The announced observations usually have to be recommended for the young teachers. A few days before the survey, the monitor (the inspector, the school principal or the monitoring group) discusses with the teacher for the lesson planning, methods, the appropriate teaching techniques, the necessary materials, by providing appropriate guidelines.

In a school where the director-teacher relations are on sound foundations, some announced visits can be realized even by the teachers themselves, by inviting the director of the school to assist in classes. This will affect the strengthening of cooperation in school and, in turn, it gives teachers the opportunity to share their experiences. 
Generally, the announced observations are organized for the teachers observed some time ago. These enable monitors to observe a lesson held in normal conditions. The teachers should not always be warned in the case they will be observed in classes, in the case we even can compare the difference of the level of the class.

\section{2. Preparation for observacion}

It is more than necessary to be prepared by the monitors before the survey. What should be done by the monitor?

To monitor the progress of the work of teachers,

To study and analyze the earlier observations,

To review the improvements in the level of teaching,

To review the curriculum of the subject,

Based on this information, the monitor identify the performance and the level of teaching, by focusing on the difficulties and obstacles that may have passed through and to see the further obligations and duties for the future.

\section{3. The process of observacion}

During the process of observation there will be raised many issues, but one of the fundamental problems is what is intended to be taught during the learning process?

During the survey, it is preferred that the observer to take notes about the situation in the class, by focusing on the teaching techniques and activities that are developing by the students. It is very important for the evaluation to be consequently documented and much more information to be gathered. This should be done throughout the class, by registering all the moments and activities conducted. During the monitoring process, the monitor should be clear that its purpose is to observe the class and not change the situation in the classroom (Sadker, M. \& Sadker, D., 1997). It is worth mentioning that some of these data that have been noted during the observation process will be presented in the figure below.

Figure 2. Taking notes on the moments and activities developed in the classroom

\section{The questions being asted to} the students

\section{The responses of the students}

\section{Taking notes}

\section{Common aktivities of teachers and students}

\section{Positive and negative practices}

Record keeping is of great importance, and the observer should be aware of the sources of taking these important notes. It is practical to monitor to sit at the end of the class behind the children, but always should have the opportunity to survey not only the teachers but also the students. The primary goal is to observe more and to practice as little intervention as possible (Sadker, M. \&Sadker, D., 1997).

\section{3. 1. The activities that could be observed during the monitoring of the classes}

In order to have more accurate results of the teaching process, the monitor can observe a variety of activities, and for this reason the position of the observer must be very interactive, so he would be able to see the face of the students and not 
only their verbal responses, but also the nonverbal ones. The expressions, comments, and student activities will provide valuable ideas on teacher-student relationships and the class nature of the activity (Sadker, M. \& Sadker, D., 1997).

Disa nga aktivitetet e mundshme të mbledhjes së të dhënave:

\section{Communication}

The level of communication

The level of communication teacher - student;

The level of communication teacher - student- teacher;

The level of communication student - student;

The level of communication student - student - teacher.

\section{The teaching process}

\section{The process of lecturing :}

How much time does the teacher spend for lecturing?

How clear the lecture of the teacher is, and how understandable and adequate it is for the students?

\section{Discussion:}

How long does the teacher communicate with the students?

How long do the students among themselves communicate?

\section{Demonstration and use of tools:}

- Demonstration (including laboratory demonstrations); didactic use of personal tools by the teacher; the use of teaching aids by the student;

- How much do the students possess the relevant texts and relevant necessary tools (pens, notebooks, rulers, paints, glue, pencil, etc. ).

\section{Assistance for the teachers:}

- The teacher provides students assistance in individual and how he can help the students in group work?

\section{Methods, techniques and strategies:}

Are the methods, techniques and defined strategies suitable and adequate for the development of teaching topic?

\section{The physical environment of the classroom:}

The physical environment of a class is convenient and it fits to the selected methods (the establishment of banks, presentation tools and teaching materials)?

\section{Individual and group work}


The Students work independently in the classroom;

How often do the students work in groups?

A teacher gives homework at the end of class?

\section{The teacher's Assistance:}

How often does the teacher provide the students with assistance in individual and how he can help the students in group work?

Table 1. The protocol model for the monitoring process in the classroom
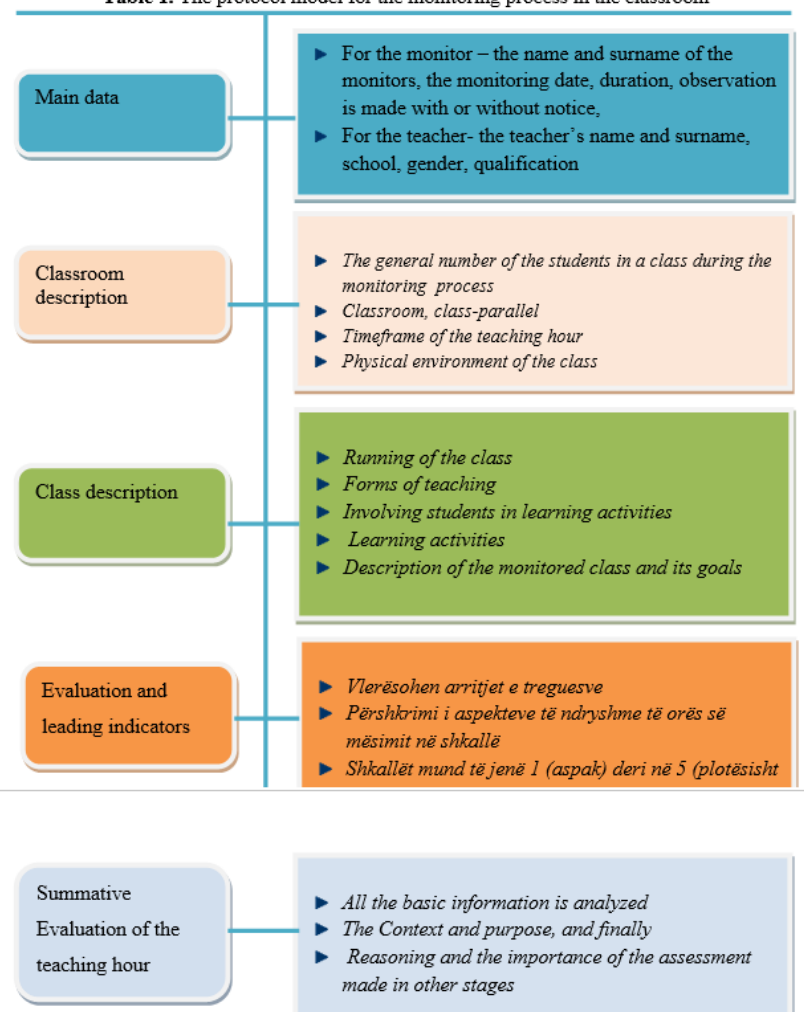

\section{The safety of students:}

Do the students work individually; Do the students feel free to express their ideas, opinions and solutions?

How much each student feels safe to express what they think and learn?

Is there an optimistic and positive environment created for the students in the classroom?

\section{The Climate class:}

Is there a positive and optimistic climate that prevails in the classroom?

\section{Homework}

Does the teacher give homework at the end of course?

Table 1. The protocol model for the monitoring process in the classroom

\section{Analysis after observacion}

After every class surveillance, there should be conducted a meeting and discussing session with the teachers. This meeting should be done immediately, because the recent activities of the monitor and teacher are fresh. The monitor, before he meets with the teacher, he must make a reflection and review over all those moments that have been marked, by taking into account the identification of positive and negative aspects.

A greater importance should be given to the meeting, where it should not be considered as a meeting where only negative remarks have been given. In order to feel comfortable and teacher meeting to be effective, the monitor task is to create a warm atmosphere and a good understanding.

Therefore, there should be developed a constructive conversation and an interactive discussion about the teaching class which occurred a few minutes ago. At the request of the monitor, the teacher makes a self-analysis of the first teaching class, which highlights the flaws and possible omissions, which may have arisen during the hour with or without a clear 
goal. Although, the monitor is familiar with some aspects of the planned teaching class, because he has already had a conversation before the class, where they have discussed the objectives, techniques and strategies that will be followed by the teacher, in order to realize the specific class. There are cases where teachers are not lacking excuses, by trying to get justifications on the idea itself, why he has acted that way.

The monitor (inspector, principal of the school etc. ) develops the conversation in these lines: - He presents the positive aspects of the teaching class,

- He covers the negative parts,

- Giving remarks,

- Giving suggestions (recommendations).

The line in which the monitor (inspectors, director etc. ) mentions the positive parts of the development process of the class by the teacher, the main aim is to stimulate and encourage the teacher by seeking consecutive improvements and not only being focused on the failures and so to create a sense of frustration or other opinion by them. Therefore, main goal is to create the atmosphere of a conversation in which monitoring-teacher dialogue has to develop in a positive and realistic aspect and without misunderstandings and prejudices.

In another line where the monitor even mention the flaws and omissions, the conversation must be very convincing so that the issuance of warnings to be convincing, so that the side of the monitor, in this case the teacher would believe or image of a monitoring and correct and fair assessment, which should be put at the service of advancement and progress. So, the monitor provides an overview of the progress of the class. In making recommendations, the monitor must be careful that they are as clear.

The teacher, in most cases, agrees with the assessment of the monitors, by contributing with comments and suggestions. The monitored teacher usually undertakes such measures that in the future will avoid omissions made during the observed class.

\section{Why should the teachers' performance be assessed?}

There are different opinions, why should the teachers' performance be evaluated, and what are the main intentions of it. The specialists in the field of education, especially those that have assessed such practices on the assessment of teachers have been giving different arguments.

According to L. Bell (1988), the evaluation of the teaching staff should be made to achieve these goals: to identify the inactive nonprofessional teachers; to increase salary and to make promotions; to provide external accountability; to improve the work / teacher performance; to make effective management of teachers; to provide professional development opportunities.

\section{Table 2. Benefits and problem end teacher appraisal}

\begin{tabular}{ll}
\hline Difficulties/ Disadvantages & Advantages and rewards \\
\hline Difficulties & Leads to the identification of clear aims and objectives \\
Suspicion & Improvers relationships \\
Concern & Provides opportunity for honest \\
& Communication, understanding, training and \\
& development \\
Lack of experience ( in self- appraisal and appraising & Displays concern and commitment \\
others) &
\end{tabular}




Training may be required
Opposition of significant groups
Disadvantages
Appraisal requires: time and commitment, especially from
senior staff honesty from all involved the need for
discipline
It can provoke conflict

Training may be required

Disadvantages

senior staff honesty from all involved the need for

It can provoke conflict
Generates motivation
It is open and seen to be open
Reduces subjectivity in assessment
Provides permanent (and available) records

Provides opportunity to praise

Person being reviewed has an ownership in the process, which leads to clearer

understanding of expectations, responsibilities

and aspirations

\section{Source: Based on L. Bell (1988)}

There are a wide range of goals and objectives related to monitoring and evaluation of teachers' performance, but there is only one major goal and that is to guarantee the quality of the teaching process. It is not enough just a simple observation of the teacher in class, the aim is to ensure that each class has a teacher professionally prepared and competent. The evaluation system should recognize, cultivate, and develop good teaching (Danielson, 2001).

Another aspect is the linking the evaluation and assessment with the increase of salary and together with it the accountability. One such way, not only will affect positively, but it likely will impact on increasing responsibility, especially among teachers with teaching deficit or professional disability. Such a model has been supported by Ingvarson and Chadbourne (1994), as a model for career development in Australia.

Many stakeholders feel that the evaluation of teachers is needed to account before a number of external partners, but especially the parents and employers. In that sense we can say that teachers should not only give an account before the inspection sector within the external evaluation and internal evaluation, but they have even greater responsibility to parents and the community.

\section{Conclusions}

This paper draws some conclusions we have reached, such as: Why should an observation be done in the class? What do we identify through a process of observation? How to conduct surveillance in a class? What do we intend through observation in class?

The survey in class is done with the purpose of impartial and objective collection of accurate information in the classroom and school;

Providing direct and constructive feedback about professional practice;

Identification of good behavior and professional practice (as in teaching, pedagogical documentation maintenance, etc. ); Identifying of the professional attitudes and practices that require further assessment and improvement;

Collection of data from diverse sources, including direct observation, interviewing and consulting;

Collection of information before and after the classroom observation, helps a fair and objective assessment.

Classroom observation can be done in two ways: direct classroom observation or video recording.

To ensure accountability, increase accountability, performance improvement, professional development opportunities, etc. 


\section{Literature}

CTL, "Criteria and procedures for evaluating performance", Pristina, 2012.

Marsh, Colin J. (2009), Basic concepts for understanding curriculum, Translated by: Center for Democratic Education (CDE), Tirana.

Inspection and internal evaluation of the school, RED / EO (Guide for complete inspection of the RED / EO's), IKAP, Tirana, 2011.

Guide to further development of quality system of external evaluation of VET in Kosovo, ACA, Pristina, 2011. Dictionary of Education, ISP, Tirana, 2003.

Sadker, M., \& Sadker, D. (1994). Failing at fairness: How our schools cheat girls. New York: Scribner's Sons.

Danielson, C. (2001). New trends in teacher evaluation. The Leadership Academy Developer, 1(3). 